\title{
Knowledge and Behaviour of Female Students in Relation to Cervical Cancer Prevention
}

1 Ivana Guljaš Slivečko

1 Zvjezdana Gvozdanović

1 GH Našice

Article received: 14.04 .2017$.

Article accepted: 15.11.2017.

Author for correspondence:

Ivana Guljaš Slivečko, GH Našice

address: Bana Jelačića 3a, 31513 Donja Motičina,

email: i.guljasslivecko@gmail.com

DOI: $10.24141 / 2 / 1 / 1 / 3$

Keywords: Prevention of cervical cancer, risk factors, cervical cancer

\section{Abstract}

Introduction. Cervical cancer is the eighth most common cancer affecting the female population in Croatia with an incidence of $13.2 / 100,000$, which is unsatisfactory in comparison with other countries. The goal of this research is to determine if there is a difference between knowledge and behaviour of female students from different universities regarding risk factors which affect the development of cervical cancer.
Participants and methods. A cross-sectional study consisting of female students attending University Undergraduate Study of Nursing (Josip Juraj Strossmayer University of Osijek, Faculty of Medicine in Osijek) and Integrated Undergraduate and Graduate Five-Year University Class Teacher Education Studies (Josip Juraj Strossmayer University of Osijek, Faculty of Teacher Education in Osijek, dislocated programme in Slavonski Brod). The research included 80 female students whose average age was 22 years. Research was conducted using an anonymous questionnaire which contained 23 questions concerning risk factors which affect the development of cervical cancer.

Results. Participants are not familiar with the risk factors that affect the development of cervical cancer, especially the students attending the Faculty of Teacher Education - 33 of them (78.6\%) (Fisher's exact test, $\mathrm{p}<0.001)$. Annually only 47 participants (58.8\%), $28(73.7 \%)$ of them attending the Faculty of Medicine, and considerably fewer, 19 participants (45.2\%) attending the Faculty of Teacher Education (Fisher's exact test, $p=0.012$ ), undergo gynaecological examinations and do Pap tests, or as recommended by their gynaecologist. The research shows that $19(45.2 \%)$ participants attending the Faculty of Teacher Education use condoms for protection, compared to $28(73.7 \%)$ participants attending the Faculty of Medicine (Fisher's exact test, $\mathrm{p}=0.0127$ ).

Conclusion. This research shows that there is a difference in the knowledge and behaviour linked to cervical cancer prevention between female students who are students of the Study of Nursing and female students of Teacher Education Studies. 


\section{Introduction}

Cervical cancer is the second most common malignancy affecting women in the world. According to the Cancer Registry of the Croatian Institute of Public Health for 2014, it is the eighth most common cancer affecting female population in Croatia, with an incidence rate of $13.2 / 100,000$, which is unsatisfactory in comparison with other countries (1). Every case of cervical cancer is a form of cancer that is one of the easiest to prevent. Cervical cancer is slow-developing, it can be seen, and diagnostics is relatively simple. Non-invasive cervical cancer is the only malignancy, other than skin cancer, where one can expect full recovery (2). The biggest problem is, however, that it is not enough to have worldclass physicians and superior medical equipment for early diagnosis of cervical cancer. The most important role is the patient's understanding of the significance of prevention, early diagnosis and regular control. We distinguish between primary and secondary prevention. The process of primary prevention includes education of adolescents, such as health education, and self-protection against the causes and risk. Currently, primary prevention includes responsible sexual behaviour, i.e. modification of sexual behaviour in terms of a smaller number of sexual partners and the improvement of sexual hygiene, including the use of condoms in accordance with the recommendations for the prevention of AIDS and sexually transmitted diseases. Special attention should be paid to health and educational activities on sexual behaviour and sexual hygiene, as well as warning about the effects of smoking and long-term use of oral contraceptives. Primary prevention is the prevention of cancer caused by HPV and the use of the HPV vaccine to reduce the risk of cervical cancer. The vaccine is effective in women aged 16 to 26. Secondary prevention means early detection of the disease, i.e. a visit to a gynaecologist and a cytological analysis at the start of sexual activity, but no later than the age of 20 , since such regular controls can detect causes of sexually transmitted infections, pre-stages and the earliest stages of cancer when it is still curable (3).

According to the data of the Institute of Public Health, infection with high-risk types of HPV is most common in adolescents and young women. It is important to check whether there is a difference in the knowledge and behaviour of respondents with regard to the type of study programme.

\section{Hypothesis}

There is a difference in the knowledge and behaviour linked to cervical cancer prevention between University Undergraduate Study of Nursing students and students of Integrated Undergraduate and Graduate Five-Year University Class Teacher Education Studies.

\section{Aims}

To determine whether there is a difference in the knowledge and behaviour of students in relation to risk factors affecting the incidence of cervical cancer according to the type of study programme - University Undergraduate Study of Nursing (Josip Juraj Strossmayer University of Osijek, Faculty of Medicine in Osijek) and Integrated Undergraduate and Graduate Five-Year University Class Teacher Education Studies (Josip Juraj Strossmayer University of Osijek, Faculty of Teacher Education in Osijek, dislocated programme in Slavonski Brod).

\section{Patients and Methods}

A cross-sectional study on female students attending the Study of Nursing and Teacher Education Studies during March and April 2013. The study included 80 female students. On the day of the survey, we found 38 of 40 respondents who were Nursing students, while we found 43 of 45 respondents at Teacher Education Studies, but one of the respondents was 27 years old and did not meet the given age criteria of 20 to 25 years. A questionnaire containing 23 items was used as a testing instrument. It included questions on knowledge and behaviour related to risk factors that affect the incidence of cervical cancer. Each question had between two and seven offered answers and the respondents were instructed to circle one or more correct answers. Questions 1-10 were related to respondents' knowledge, and questions 11-23 were related to their behaviour. 


\section{Ethics}

All respondents were aware of the aim of the research and gave their consent to participate.

\section{Statistics}

The results are shown using basic measures of arithmetic mean and scattering. Normality of the observed numerical variables was tested using the KolmogorovSmirnov test. Categorical variables are described in absolute and relative frequencies.

The differences between categorical variables were tested using the $\chi 2$ test and the Fisher's exact test. For the assessment of significance of the results, significance level of $\alpha=0.05$ was chosen.

Original written programs for databases and the statistical package Statistica for Windows 2005 (version 7.1, StatSoft Inc., Tulsa, OK, USA) were used.

\section{Results}

Significantly less knowledge was shown by respondents from the Teacher Studies who did not know that the Pap test is an effective method for early detection of cervical cancer (Fisher's exact test, $p=0.005$ ) and that changing sexual partners is a risk factor for cervical cancer (Fisher's exact test, p <0.001).

Also, significantly more correct answers were given by the respondents from the Study of Nursing to the statement that HPV is one of the causes of cervical cancer (Fisher's exact test, $\mathrm{p}<0.001$ ) compared to 14 (33\%) respondents from Teacher Education Studies who responded that they did not know the answer.

23 (54\%) respondents from Teacher Education Studies did not know that early pregnancy is a risk fac- tor for the development of cervical cancer, and 11 $(26.2 \%)$ considered that to be an incorrect statement (Fisher's exact test, $p=0.003$ ). Significantly fewer respondents from Teacher Education Studies knew about the HPV vaccine, which reduces the risk of cervical cancer (Fisher's exact test, p <0.001) (Table 1).

More than half of the respondents do not know what the risk factors for cervical cancer are.

Significantly more respondents studying Nursing know that smoking cigarettes is a risk factor (Fisher's exact test, $p<0.001$ ), as well as a larger number of pregnancies (Fisher's exact test, $p=0.024$ ).

Significantly more respondents studying at Teacher Education Studies, 33 (78.6\%) (Fisher's exact test, p $<0.001)$, do not know risk factors for the development of cervical cancer (Table 2).

A gynaecological examination and Pap screening are performed once a year or as recommended by a gynaecologist by 47 (58.8\%) respondents, of which 28 (73.7\%) from the Study of Nursing and significantly less, $19(45.2 \%)$ respondents, from Teacher Education Studies (Fisher's exact test, $\mathrm{p}=0.012$ ) (Table 3 ).

Respondents from the Study of Nursing had significantly more sexual partners in the past year (Fisher's exact test, $p=0.015$ ) (Table 4). The number of women who do not tend to have simultaneous relationships with several partners is equal in both groups, $75(93.8 \%)$. In the past year, 1-2 genital infections were experienced by $18(22.5 \%)$ respondents. Only two participants in the total sample had 3-4 infections, both from the Study of Nursing.

When suffering from a genital infection, 53 (66.3\%) respondents visit their gynaecologist, 14/80 treat it on their own, 12 (15\%) of them wait for the infection to subside on its own, and only $6(7.5 \%)$ inform their partners and are treated together (Table 4).

$17(21.3 \%)$ respondents smoke cigarettes every day, $9(11.3 \%)$ smoke sometimes, which is equal in both groups. Significantly more respondents, 21 (50\%) of them, from Teacher Education Studies never or rarely use contraception compared to Study of Nursing students (Fisher's exact test, $\mathrm{p}=0.020$ ) (Table 5).

Fewer respondents, 19 (45.2\%) of them from Teacher Education Studies use a condom, compared to 28 (73.7\%) of Study of Nursing respondents (Fisher's exact test, $p=0.0127$ ). Significantly more participants from Teacher Education Studies do not use 


\section{Table 1. Distribution of respondents according to questions regarding knowledge on sexual and health behaviour and by study programme \\ Knowledge \\ Study of Nursing \\ Number (\%) of respondents}

First gynaecological examination should be performed before turning 20 .

$\begin{array}{cccc}\text { correct } & 35(92.1) & 36(85.7) & 71(88.8) \\ \text { incorrect } & 3(7.9) & 3(7.1) & 6(7.5) \\ \text { do not know } & 0 & 3(7.1) & 3(3.8)\end{array}$

Early start of sexual activity is if a person is sexually active before turning 18.

$\begin{array}{cccc}\text { correct } & 35(92.1) & 38(90.5) & 73(91.3) \\ \text { incorrect } & 3(7.9) & 1(2.4) & 4(5) \\ \text { do not know } & 0 & 3(7.1) & 3(3.8)\end{array}$

The Pap test is an effective method for early detection of cervical cancer.

$\begin{array}{cccc}\text { correct } & 38(100) & 33(78.6) & 71(88.8) \\ \text { incorrect } & 0 & 5(11.9) & 5(6.3) \\ \text { I do not know } & 0 & 4(9.5) & 4(5)\end{array}$

Changing sexual partners is a risk factor for cervical cancer development.

$\begin{array}{ccccc}\text { correct } & 38(100) & 25(59.5) & 63(78.8) & \\ \text { incorrect } & 0 & 7(16.7) & 7(8.8) & <0.001 \\ \text { I do not know } & 0 & 10(23.8) & 10(12.5) & \end{array}$

First pregnancy at an early age is not a risk factor for cervical cancer development.

\begin{tabular}{|c|c|c|c|c|}
\hline correct & $11(28.9)$ & $8(19)$ & $19(23.8)$ & \\
\hline incorrect & $20(52.6)$ & $11(26.2)$ & 31 (38.8) & 0.003 \\
\hline I do not know & $7(18.4)$ & $23(54.8)$ & 30 (37.5) & \\
\hline \multicolumn{5}{|c|}{ HPV is one of the causes of cervical cancer development. } \\
\hline correct & $38(100)$ & 26 (61.9) & $64(80)$ & \multirow{3}{*}{$<0.001$} \\
\hline incorrect & 0 & $2(4.8)$ & $2(2.5)$ & \\
\hline I do not know & 0 & $14(33.3)$ & $14(17.5)$ & \\
\hline \multicolumn{5}{|c|}{ The HPV vaccine exists and reduces the risk of cervical cancer development. } \\
\hline correct & $36(94.7)$ & $16(38.1)$ & $52(65)$ & \multirow{3}{*}{$<0.001$} \\
\hline incorrect & $1(2.6)$ & $1(2.4)$ & $2(2.5)$ & \\
\hline I do not know & $1(2.6)$ & 25 (59.5) & $26(32.5)$ & \\
\hline \multicolumn{5}{|c|}{ Frequent gynaecological infections play a role in cervical cancer incidence. } \\
\hline correct & $26(68.4)$ & $20(47.6)$ & $46(57.5)$ & \multirow{3}{*}{0.054} \\
\hline incorrect & $6(15.8)$ & 5 (11.9) & $11(13.8)$ & \\
\hline I do not know & $6(15.8)$ & $17(40.5)$ & $23(28.8)$ & \\
\hline TOTAL & $38(100)$ & $42(100)$ & $80(100)$ & \\
\hline
\end{tabular}




\section{Table 2. Distribution of respondents according to questions regarding risk factors by study} programme

\begin{tabular}{|c|c|c|c|c|}
\hline Risks & Study of Nursing & $\begin{array}{l}\text { Number (\%) of respondents } \\
\text { Teacher Education Studies }\end{array}$ & Total & $\mathbf{p}^{*}$ \\
\hline \multicolumn{5}{|c|}{ Smoking } \\
\hline no & 15 (39.5) & $34(81)$ & 49 (61.3) & \multirow{2}{*}{$<0.001$} \\
\hline yes & $23(60.5)$ & 8 (19) & $31(38.8)$ & \\
\hline \multicolumn{5}{|c|}{ Breastfeeding } \\
\hline no & 37 (97.4) & $42(100)$ & 79 (98.8) & \multirow{2}{*}{0.475} \\
\hline yes & $1(2.6)$ & $0(0)$ & $1(1.3)$ & \\
\hline \multicolumn{5}{|c|}{ Multiparas } \\
\hline no & 31 (81.6) & $41(97.6)$ & $72(90)$ & \multirow{2}{*}{0.024} \\
\hline yes & 7 (18.4) & $1(2.4)$ & $8(10)$ & \\
\hline \multicolumn{5}{|c|}{ I do not know } \\
\hline no & $25(65.8)$ & $9(21.4)$ & $34(42.5)$ & \multirow{2}{*}{$<0.001$} \\
\hline yes & 13 (34.2) & 33 (78.6) & $46(57.5)$ & \\
\hline
\end{tabular}

\section{Table 3. Distribution of answers by questions on behaviour}

Behaviour

I did not

12 to 15 years

16 to 18 years

18 years or older

\begin{tabular}{|c|c|c|c|c|}
\hline I did & $12(31.6)$ & $7(16.7)$ & 19 (23.8) & \multirow{2}{*}{$0.188^{\dagger}$} \\
\hline I did not & $26(68.4)$ & 35 (83.3) & $61(76.3)$ & \\
\hline \multicolumn{5}{|c|}{ Your first intercourse was at the age of: } \\
\hline 12 to 15 years & $1(2.6)$ & $1(2.4)$ & $2(2.5)$ & \multirow{4}{*}{0.060} \\
\hline 16 to 18 years & $27(71.1)$ & $21(50)$ & $48(60)$ & \\
\hline 18 years or older & $10(26.3)$ & $15(35.7)$ & $25(31.3)$ & \\
\hline I have not had intercourse & 0 & 5 (11.9) & $5(6.3)$ & \\
\hline \multicolumn{5}{|c|}{ I visit my gynaecologist and do the Pap test: } \\
\hline $\begin{array}{l}\text { once a year, or as recommende } \\
\text { by my gynaecologist }\end{array}$ & 28 (73.7) & $19(45.2)$ & $47(58.8)$ & \multirow{4}{*}{0.012} \\
\hline when I remember to do it & $3(7.9)$ & $1(2.4)$ & $4(5)$ & \\
\hline when I have problems & $2(5.3)$ & $6(14.3)$ & $8(10)$ & \\
\hline I do not visit one & $5(13.2)$ & $16(38.1)$ & $21(26.3)$ & \\
\hline \multicolumn{5}{|c|}{ Have you been vaccinated against the Human papillomavirus (HPV)? } \\
\hline yes & 0 & $1(2.4)$ & $1(1.3)$ & \multirow{2}{*}{0.338} \\
\hline no & $38(100)$ & $41(97.6)$ & $79(98.8)$ & \\
\hline \multicolumn{5}{|c|}{ If you were given the opportunity to be vaccinated against the HPV virus for free, would you do it? } \\
\hline yes & $18(47.4)$ & $14(33.3)$ & $32(40)$ & \multirow{3}{*}{0.200} \\
\hline no & $10(26.3)$ & $9(21.4)$ & $19(23.8)$ & \\
\hline I have not thought about it & $10(26.3)$ & $19(45.2)$ & 29 (36.3) & \\
\hline Total & 38 (100) & $42(100)$ & $80(100)$ & \\
\hline
\end{tabular}

I have not had intercourse

\section{Study of Nursing}

\section{Number (\%) of respondents}

Did you visit a gynaecologist before your first intercourse?

* Fisher's exact test; ' $\chi^{2}$ test 


Table 4. Distribution of answers by questions on behaviour
$\begin{array}{llll}\text { Behaviour } & \text { Number (\%) of respondents } \\ \text { Study of Nursing } & \begin{array}{c}\text { Teacher Education } \\ \text { Studies }\end{array} & \text { Total }\end{array}$ P $^{*}$

In the previous year, I had the following number of sexual partners:

I did not have sexual partners

$$
\begin{aligned}
& 1 \text { - } 2 \text { partners } \\
& 3 \text { - } 4 \text { partners }
\end{aligned}
$$

5 and more partners

0
$35(92.1)$
$1(2.6)$
$2(5.3)$

$6(14.3)$

$$
36(85.7)
$$$$
0
$$$$
0
$$

Do you tend to have simultaneous sexual relationships with two or more partners?

$\begin{array}{cccc}\text { yes } & 0 & 1(2.4) & 1(1.3) \\ \text { no } & 35(92.1) & 40(95.2) & 75(93.8) \\ \text { sometimes } & 3(7.9) & 1(2.4) & 4(5)\end{array}$

$6(7.5)$

In the previous year, I had:
1 - 2 genital infections
3 - 4 genital infections
11 (28.9)
2 (5.3)
7 (16.7)
0
25 (65.8)
35 (83.3)
18 (22.5)
2 (2.5)
0.085
I did not have any infections
60 (75)

Affirmative a
Visit a gynaecologist
Treat it on their own

$$
\begin{gathered}
29 \text { (76.3) } \\
7(18.4)
\end{gathered}
$$

24 (57.1)

7 (16.7)

1 (1.3)

$2(2.5)$

0.015

Wait until it subsides on its own

$3(7.9)$

$9(21.4)$

4 (10.5)

$2(4.8)$

$42(100)$

0.341

Notify the partners and treat it together

38 (100)

TOTAL

* Fisher's exact test; ' $\chi^{2}$ test

\section{Table 5. Habits of respondents regarding smoking and the use of contraception}

\section{Number (\%) of respondents}

\section{Table 5 . Habits
Respondents' habits}

Teacher Education Studies
Total

$\begin{array}{cc}53(66.3) & 0.098^{\dagger} \\ 14(17.5) & 0.837^{\dagger} \\ 12(15) & 0.121 \\ 6(7.5) & 0.416 \\ 80(100) & \end{array}$

Study of nursing

Do you smoke?

\begin{tabular}{ccccc} 
yes & $8(21.1)$ & $9(21.4)$ & $17(21.3)$ & \\
no & $27(71.1)$ & $27(64.3)$ & $54(67.5)$ & $0.695^{\dagger}$ \\
sometimes & $3(7.9)$ & $6(14.3)$ & $9(11.3)$ & \\
Never or rarely & \multicolumn{2}{c}{ I use contraception. } & $29(36.3)$ \\
sometimes & $8(21.1)$ & $21(50)$ & $12(15)$ & $\mathbf{0 . 0 2 0}$ \\
Often and always & $6(15.8)$ & $6(14.3)$ & $39(48.8)$ & $80(100)$
\end{tabular}


any contraception, 10 (23.8\%) of them, compared to $2(5.3 \%)$ of Study of Nursing respondents (Fisher's exact test, $p=0.020$ ) (Figure 1 ).

Our respondents have exhibited almost all risk behaviours.

Statistically significantly more students from Teacher Education Studies had no sexual partners in the last year. Significantly more students from Teacher Education Studies have never had a gynaecological examination. Regarding contraception, they mostly use coitus interruptus.

Higher risk of participants from the Study of Nursing is shown by the fact that in the last year they had five or more partners and that their first sexual intercourse was between the age of 12 and 15 .

More of them also smoke, and if they get a gynaecological infection, 9 (20.4\%) of them wait until it subsides (Table 6).

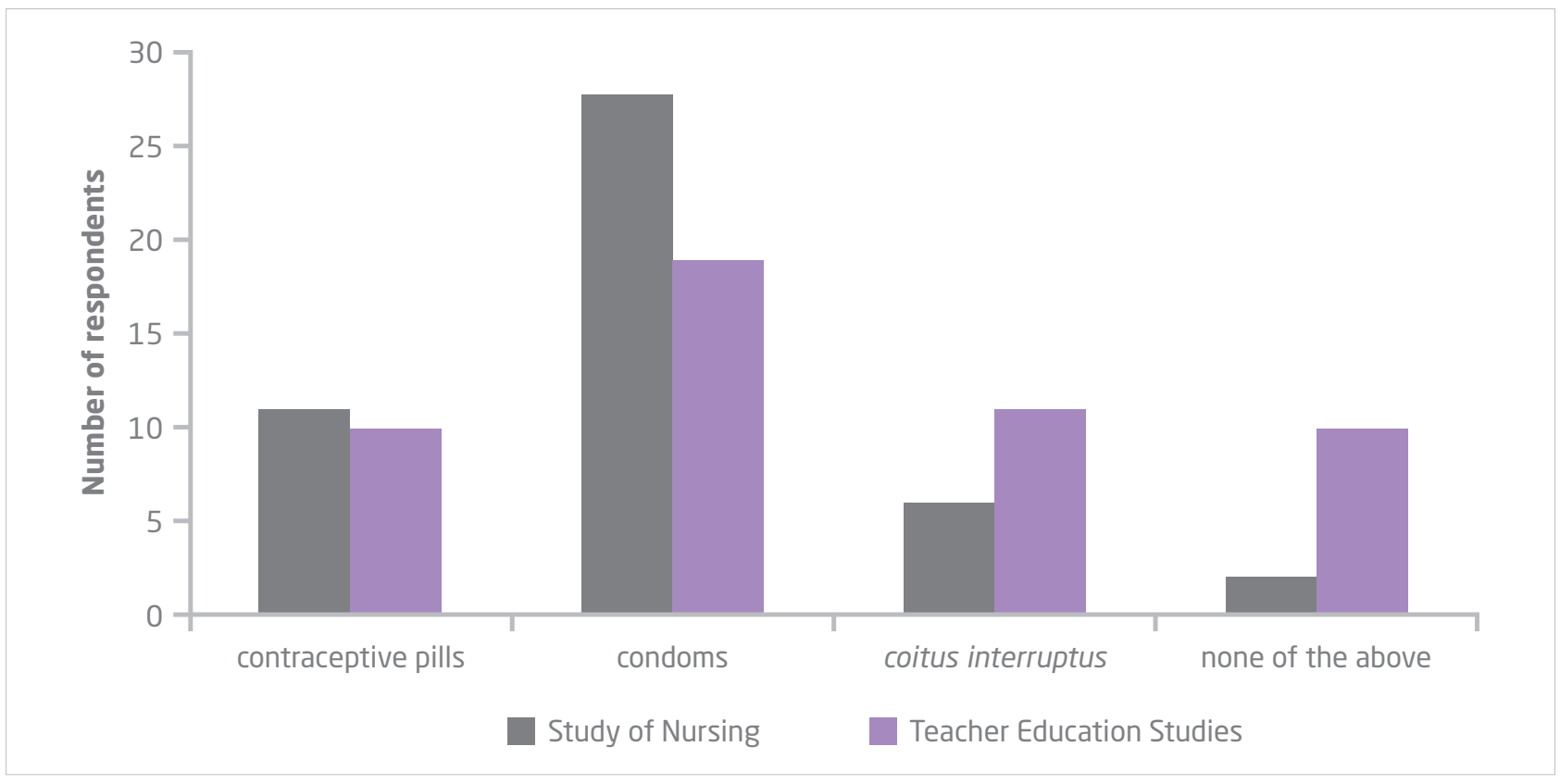

Figure 1. Use of contraception by study programme

\section{Table 6. Distribution of respondents according to risky sexual behaviour by study programme}

\begin{tabular}{|c|c|c|c|}
\hline \multirow[b]{2}{*}{ Risk } & \multicolumn{3}{|c|}{ Number (\%) of respondents } \\
\hline & $\begin{array}{l}\text { Study of } \\
\text { Nursing }\end{array}$ & $\begin{array}{c}\text { Teacher Education } \\
\text { Studies }\end{array}$ & Total \\
\hline Not vaccinated against HPV & $38(100)$ & $41(97.6)$ & $79(98.8)$ \\
\hline Did not visit a gynaecologist before the start of sexual activity & $26(68.4)$ & 35 (83.3) & $61(76.3)$ \\
\hline Use contraception rarely or never & $8(21.1)$ & $21(50)$ & $29(36.3)$ \\
\hline Do not visit a gynaecologist & $5(13.2)$ & $16(38.1)$ & $21(26.3)$ \\
\hline Contraception - coitus interruptus & $6(15.8)$ & $11(26.2)$ & $17(21.3)$ \\
\hline Smoke & $8(21.1)$ & $9(21.4)$ & $17(21.3)$ \\
\hline Wait until a gynaecological infection subsides on its own & $3(7.9)$ & $9(21.4)$ & $12(15)$ \\
\hline Contraception - none of the above & $2(5.3)$ & $10(23.8)$ & $12(15)$ \\
\hline 5 or more sexual partners in the previous year & $2(5.3)$ & 0 & $2(2.5)$ \\
\hline First sexual activity at the age between 12 and 15 & $1(2.6)$ & $1(2.4)$ & $2(2.5)$ \\
\hline Simultaneous sexual relationships with two or more partners & 0 & $1(2.4)$ & $1(1.3)$ \\
\hline
\end{tabular}


The person they mention as someone they can openly talk to about sexual relationships and sexual issues is a male friend or a female friend for $64(80 \%)$ subjects, significantly more from the Study of Nursing, i.e. 37 (97.4\%) (Fisher's exact test, $\mathrm{p}<0.001)$.

Another person with whom they can talk openly is their partner, in both study groups equally. The person they believe can help them the least is a family physician. None of the respondents listed their teachers as someone they can openly talk to (Table 7).

\section{Discussion}

Since this is a health-related topic, it is not surprising that nursing students have better knowledge, and that the connection between their knowledge and behaviour is optimistic. This difference can be explained by the fact that nurses are educated about health promotion and disease prevention, early screening and disease detection. Sexual health education level is an important prerequisite for long-term health and quality of living, but it is obviously lacking in the area of formal education of non-nursing students.

Participants from Teacher Education Studies know significantly less about the fact that the Pap test is an effective method for early detection of cervical cancer. Also, significantly less of them know that changing sexual partners is a risk factor for cervical cancer. Similar results were obtained in a study on awareness and preventive behaviour related to cer- vical cancer development on a sample of 205 firstyear students at the University of Mangosuthu in South Africa; $31 \%$ of students heard about the Pap test, and a third of them, 33\%, knew that the test is used to detect or prevent cervical cancer. Furthermore, one third of respondents, 32\%, and more than a quarter of them, $26 \%$, knew about the HPV virus and that a large number of sexual partners was a risk factor for cervical cancer (4).

Participants from Teacher Education Studies know significantly less about risk factors for cervical cancer. Participants from the Study of Nursing gave significantly more correct answers to the claim that HPV is one of the causes of cervical cancer compared to the participants from Teacher Education Studies. Participants from Teacher Education Studies know significantly less that there is the HPV vaccine that reduces the risk of cervical cancer. Participants from the Study of Nursing know significantly more that smoking cigarettes and a larger number of pregnancies are risk factors. In a similar study conducted in Turkey, nursing students received similar results, as much as $90.5 \%$ of respondents reported that HPV can cause cervical cancer (5). In a study on the knowledge about risk factors associated with the development of cervical cancer among 140 students in Ghana, the results showed low levels of knowledge about the connection between HPV and cervical cancer, i.e. only $7.9 \%$, or smoking and cervical cancer - only $1 \%$ (6). According to the American Cancer Society, women who smoke are about twice as likely to develop cervical cancer (7).

More than half of participants from Teacher Education Studies do not know that early pregnancy is a risk factor for cervical cancer, and some of them disagree with this statement. At the University of Mangosuthu in South Africa, among female students who

\begin{tabular}{|c|c|c|c|c|}
\hline \multirow{2}{*}{ Person I can openly talk to } & \multicolumn{3}{|c|}{ Number $(\%)$ of respondents } & \multirow{2}{*}{$\mathbf{p}^{*}$} \\
\hline & Study of Nursing & Teaching Education Studies & Total & \\
\hline mother & 11 (28.9) & $14(33.3)$ & 25 (31.3) & 0.810 \\
\hline friend & $37(97.4)$ & $27(64.3)$ & $64(80)$ & $<0.001$ \\
\hline partner & $24(63.2)$ & $27(64.3)$ & $51(63.8)$ & 0.917 \\
\hline family physician & $1(2.6)$ & $1(2.4)$ & $2(2.5)$ & 0.728 \\
\hline gynaecologist & $12(31.6)$ & $16(38.1)$ & $28(35)$ & 0.354 \\
\hline
\end{tabular}


were 19.5 years of age, as much as 30.4\% stated they had been pregnant (4). British scientists have found that girls who have previously entered sexual intercourse have twice the chance of developing cervical cancer. They came to this conclusion after a survey of 20,000 women (8).

Gynaecologic examinations and Pap tests are performed once a year or as recommended by the gynaecologist in the case of $47(58.8 \%)$ respondents, $28(73.7 \%)$ of which are students of Nursing and significantly less, 19 (45.2\%) attending Teacher Education Studies. According to individual reports on general medical examinations during the first year of study for the academic year 2005/2006, the average age of entering into sexual relations was around 17 years (9). What is worrisome is the fact that $48 \%$ of sexually active girls did not visit a gynaecologist until a general medical examination (9).

Significantly more sexual partners in the past year were reported by participants studying nursing. A similar study was conducted by Denny-Smith on a sample of 240 nursing students and showed that students participate in high-risk sexual behaviours, but unlike our respondents, they also showed a low level of knowledge (10). Such a situation can be explained by earlier physical and sexual maturity, longer education, and later marriage arrangements. Curiosity, ignorance, peer pressure, emotional immaturity with sexual intercourse etc. lead young people to risky sexual behaviour (11).

Significantly more students from Teacher Education Studies never or rarely use contraception compared to participants from the Study of Nursing. Fewer participants from Teacher Education Studies use a condom. These figures are lower than the data obtained at the University of Mangosuthu in South Africa where as much as $78 \%$ of students said they used condoms, and $56 \%$ of them stated that they used condoms during every sexual relationship (4). Significantly, none of these contraceptive methods are used by the students of Teacher Education Studies. According to individual reports on general medical examinations during the first year of study for the academic year 2005/2006, the use of condoms among the student population is unsatisfactory (9). Of those who are sexually active, up to $27 \%$ of girls stated that they rarely use condoms or do not use them at all (9).

The person who participants listed as someone they can openly talk to about sexual relations and sexual problems is a friend, significantly more from the Study of Nursing. Young people receive health information from formal (school, books, doctors), but also from informal (friends, family, magazines, media, internet) sources (9). In RAR (Rapid Assessment and Response) research conducted among the most vulnerable groups of young people in 2002, friends are listed at the top, followed by the media, and only then by school and family (11). Janković has analysed students' attitudes and has concluded that it is sometimes unpleasant for young people to talk to their parents, even though parents and experts in schools are believed to be the best source of information (12).

We consider that the shortcoming of this study is a small number of respondents, and that a larger number of respondents should be involved in future research.

\section{Conclusions}

This research shows that there is a significant difference between the knowledge and behaviour of female students who attend University Undergraduate Study of Nursing and female students of Integrated Undergraduate and Graduate Five-Year University Class Teacher Education Studies. Thus, the hypothesis is confirmed.

In this study, we can see the lack of information and education, especially of Teacher Education Studies students and that education on sexual health and responsible sexual behaviours is very much needed. The preservation of reproductive health of young people is an important factor not only for their own well-being, but also for the progress of the whole society. Careless and irresponsible sexual behaviour of young people can have direct, but also long-term consequences. This study clearly shows that there is room for the necessary interventions in the work of all health care professionals and in health education, the fundamental activity of primary prevention.

Health education should provide science-based information and facts, and influence attitudes and values.

Schools have a central role, and health education is an essential part of a comprehensive program. However, behaviours cannot change without the involvement of families and wider community. 


\section{Acknowledgments}

We wish to thank Đurđica Kašuba Lazić, MD, MSc, for helping us with this paper. A special acknowledgment goes to all of our respondents.

\section{References}

1. Croatian Institute of Public Health. Croatian National Cancer Registry 2014 [In Croatian].[cited 2017 May 31]. Available from: http://www.hzjz.hr/wp-content/ uploads/2013/11/Bilten-2014_final.pdf

2. Eljuga D, Dražančić $A$. Prevention and Diagnosis of Tumors of Female Sex Organs [In Croatian]. Zagreb: Nakladni zavod Globus; 1998.

3. Čolak Z. Infections of Human Papillomavirus [In Croatian]. Svijet Zdravlja: 2006; 10:4-7.

4. Hoque ME. Cervical Cancer Awareness and Preventive Behaviour among Female University Students in South Africa. Asian Pac J Cancer Prev. 2010;11:127-130.

5. Bal-Yilmaz H, Koniak-Griffin D. Knowledge, Behaviors, and Attitudes about Human Papilloma Virus among Nursing Students in Izmir, Turkey. J Cancer Educ. [cited 2017 November 2]. Available from: https://doi.org/10.1007/ s13187-017-1163-1

6. Abotchie PN, Shokar NK. Cervical Cancer Screening Among College Students in Ghana: Knowledge and Health Beliefs. Gynecol Cancer. 2009; 19(3):412-416.

7. American Cancer Society [Internet]. What are the risk factors for cervical cancer? [cited 2017 May 31]. Available from: https://www.cancer.org/cancer/cervical-cancer/causes-risks-prevention/risk-factors.html

8. Franceschi S, Plummer M, Clifford G, de Sanjose S, Bosch X, Herrero R, et al. Differences in the risk of cervical cancer and human papilloma virus infection by education level. $\mathrm{Br}$ J Cancer. 2009; 101:865-870.

9. Kuzman M, Pejnović Franelić I, Pavić Šimetin I. Sexual behaviour of Adolescents in Croatia and Education about HPV Protection [In Croatian]. Medix. 2007; 72.73:79-83.

10. Denny-Smith T, Bairan A. A survey of female nursing students' knowledge, health beliefs, perceptions of risk, and risk behaviors regarding human papillomavirus and cervical cancer. J Am Acad Nurse Pract. 2006;18(2):62-69.

11. Mojsović Z . Nursing in community. Zagreb: University of Applied Health Sciences; 2006.

12. Janković S. The needs and expectations of adolescents in acquiring knowledge and promoting reproductive health [master thesis]. University of Zagreb: School of Medicine: Zagreb 2005. 


\section{ZNANJE I PONAŠANJE STUDENTICA VEZANO UZ PREVENCIJU RAKA VRATA MATERNICE}

\section{Sažetak}

Uvod. Rak vrata maternice u Hrvatskoj se nalazi na osmom mjestu najčešćih sijela raka u ženske populacije sa stopom učestalosti od 13,2 na 100 000, što nije zadovoljavajuće u usporedbi s drugim zemljama. Cilj ovog istraživanja bio je utvrditi postoji li razlika u znanju i ponašanju studentica u vezi s čimbenicima rizika koji utječu na pojavnost raka vrata maternice $s$ obzirom na vrstu studija.

Ispitanici i metode. Presječenom studijom obuhvaćene su studentice sveučilišnog preddiplomskog studija sestrinstva i studentice integriranog preddiplomskog i diplomskog sveučilišnog učiteljskog studija. U istraživanju je sudjelovalo 80 ispitanica prosječne životne dobi 22 godine. Ispitivanje je provedeno anonimnim anketnim upitnikom koji je sadržavao 23 pitanja koja su se odnosila na čimbenike rizika koji utječu na pojavnost raka vrata maternice.

Rezultati. Ispitanice s Učiteljskog fakulteta u znatno većem broju odgovaraju da ne poznaju čimbenike rizika za nastanak raka vrata maternice, njih 33 (78,6 \%) (Fisherov egzaktni test, $p<0,001$ ). Ginekološke preglede i uzimanje PAPA testa testa 47 (58,8 \%) ispitanica obavlja jednom godišnje ili po preporuci ginekologa, od čega $28(73,7 \%)$ sa studija sestrinstva i znatno manje, 19 (45,2 \%), s Učiteljskog fakulteta (Fisherov egzaktni test, $p=0,012$ ). Manje ispitanica, njih 19 (45,2 \%) s učiteljskog studija upotrebljava kondom, u usporedbi sa $28(73,7 \%)$ studentica studija sestrinstva (Fisherov egzaktni test, $\mathrm{p}=0,0127$ ).
Zaključak. Iz provedenog istraživanja možemo zaključiti da između studentica studija sestrinstva i studentica učiteljskog studija postoji razlika u znanju i ponašanju povezanom s prevencijom raka vrata maternice.
Ključne riječi: prevencija raka vrata maternice, rizični čimbenici i rak vrata maternice 